\title{
Public Accounting and Sustainability: An academic approach
}

\section{La Contaduría Pública y la Sostenibilidad: Una visión académica}

\author{
BERTTOLINI-DÍAZ Gilda María, GONZÁLEZ-LÓPEZ Olga Yeri, PÉREZ-CANO Marina and \\ IRETA-LÓPEZ Hugo
}

Universidad Juárez. Autónoma de Tabasco. Avenida Universidad s/n, Zona de la Cultura, Col. Magisterial C.P. 86040

ID $1^{\text {st }}$ Author: Gilda María, Berttolini-Díaz / ORC ID: 0000-0001-5889-4420, Researcher ID Thomson: N-1435-2017, CVU CONACYT ID: 670973

ID $1^{\text {st }}$ Coauthor: Olga Yeri, González-López / ORC ID: 0000-0002-4157-8840, Researcher ID Thomson: T-1683-2018, CVU CONACYT ID: 336574

ID $2^{\text {nd }}$ Coauthor: Marina, Pérez-Cano / ORC ID: 0000-0003-0181-3962, Researcher ID Thomson: D-6457-2018, CVU CONACYT ID: 544704

ID $3^{\text {rd }}$ Coauthor: Hugo, Ireta-López / ORC ID: 0000-0002-23R-6429, Researcher ID Thomson: S-8676-2018, CVU CONACYT ID: 947616

DOI: $10.35429 / J H R T .2019 .16 .5 .9 .18$

Received: June 30, 2019; Accepted: December 20, 2019

\begin{abstract}
Environmental education emerges as a crucial need in today's circumstances, in academic contexts such as universities, it implies introducing environmental contents and criteria in the corpus of knowledge, skills, attitudes and values outlined in the curricula, which could allow the students to perform professionally in environmental schemes and circumstances. The objective of this essay is to analyze: 1) The insertion of the issue of Sustainable Development in Public Accounting, and 2) To identify the different possible approaches to Sustainable Development in the curricula. The environmental framework represents an innovation in the curricula development, since it highlights not only the human being as an individual and the society as important participants in this issue, but also the global environment in a double role, both as a partaker and a mediating element for a new society, Chacón, 2004 quoted by (Cóndor, 2018). Starting from the fact that universities have included the environmental framework in their programs and as part of their quality standards, we analyze how sustainability is insert in the Public Accounting Degree since the curriculum was restructured in 2015 (DACEA-UJAT. LCP. 206). An exploratory analysis is undertaken, to compare UJAT with other universities in Mexico by identifying indicators that represent the insertion of this framework with a transversal design among institutions and their curricula. The main goal is to strengthen the outline and contents of the subject Accounting for Sustainability.
\end{abstract}

Sustainable development, Curricula, Public Accounting

\begin{abstract}
Resumen
La educación ambiental surge como una necesidad, en las universidades implica considerar contenidos y criterios ambientales a los conocimientos, habilidades, actitudes y valores en los programas de estudio, que permitan a los estudiantes, desempeñarse profesionalmente en esquemas ambientales. El objetivo del documento es analizar: 1.La inserción del Desarrollo Sostenible en la Contaduría Pública y 2. Identificar los enfoques del Desarrollo Sostenible en los programas de estudio. La dimensión ambiental es innovadora en el enfoque curricular, puesto que visualiza no solo al ser humano y la sociedad como actores, sino al ambiente global en una doble función como actor y como instancia mediatizadora para una nueva sociedad, Chacón, 2004 citado por (Cóndor, 2018). Las universidades han incorporado la dimensión ambiental en los curriculum como indicadores de calidad, se analiza la inserción de la sostenibilidad en los programas de estudio a partir de la reestructuración del plan de estudios 2015 de la Licenciatura en Contaduría Pública, (DACEA-UJAT. LCP. 2016). Se realiza un análisis exploratorio con otras universidades del País para identificar los indicadores detonantes que conforman la inserción de esta dimensión con un diseño transversal, para demostrar la participación en los programas de estudio. Se propone fortalecer los contenidos temáticos de la Contabilidad para la Sostenibilidad.
\end{abstract}

Desarrollo sostenible, Programas de Estudio, Contaduría Pública

Citation: BERTTOLINI-DÍAZ Gilda María, GONZÁLEZ-LÓPEZ Olga Yeri, PÉREZ-CANO Marina and IRETA-LÓPEZ Hugo. Public Accounting and Sustainability: An academic approach. Journal of Human Resources Training. 2019, 5-16: 9-18

\footnotetext{
*Correspondence to Author (gildaberttolini@ hotmail.com)

$\dagger$ Researcher contributing first Author
} 


\section{Introduction}

Díaz (2016) points out that in the basic documents of the educational reforms institutional educational models and curricular proposals -, they express the need to meet the demands of an increasingly globalized society, the so-called knowledge society, so that educational approaches are They are currently focused on ensuring that development is sustainable to meet the needs demanded by the profession, responding to various policies emanating from national and international organizations.

Within the framework of education, sustainable development promotes prosperity and economic opportunities, social welfare and environmental protection. We want to grow together transforming ourselves into a more just and equitable society. We also want to prosper in the present but without compromising the resources of the future. Recovered from http://www.onu.org.mx/que-es-el-desarrollo. It is also the management and conservation of the natural resource base and the orientation of technological and institutional change, which ensures the continuity of human needs for present and future generations.

In the Academic Division of Administrative Economic Sciences -DACEA hereafter-, in 2016 the Degree Program in Accounting was restructured in accordance with what is dictated by the Educational Policy and national and international guidelines on Higher Education and needs of the work environment demanded by various studies conducted to the business and social sector The restructuring allowed to design the subjects by competences, transforming the thematic contents towards an ethical and sustainable development by competences, according to the demands of society in the globalized environment of Higher Education.

\section{Justification}

The environmental training of the accountants must have the knowledge, skills and attitudes necessary for the proper management of the environmental problems of the professional field in which it develops and the community in which it lives, Ibarra 1995 (cited in Ibarra 1997). Currently the environmental impact highlights the need to articulate plans, programs, policies between states, companies and citizens;
This requires information systems that allow the management of the environmental dimension. The scope of accounting as a science, exceeds the frontiers of financial, administrative and economic rationality in companies and in society itself, goes beyond the disclosure of economic and financial information; The current accounting paradigm considers social welfare and the promulgation of sustainable environments and ecosystems. Pacheco e Higuera, 2017 cited by. (Higuera, Pacheco, Londoño, Cuellar and González, 2017).

To argue that there is a theory of connectivity between research, accounting science and the preservation of the environment, is a more human than dogmatic purpose, since accounting allows establishing an environmental and / or natural control through which it is assigned and it represents a role to nature in social dynamics and at the same time the ways in which man appropriates it are established. (Quinche, 2006).

The challenge lies in higher education institutions, analyzing the possibility of modifying the teaching of the cost structure in the Public Accounting career, to make the future professional an integral being, capable of responding to the needs of business dynamics current, which not only benefits companies but also the disciplinary work of the public accountant (Hernández, 2019)

\section{Problem}

The term Sustainable Development is often confused with that of Sustainable Development and in this regard, the dictionary of the Royal Spanish Academy (RAE, 2019), defines Sustainable, as that [That can be sustained, especially in ecology and economy, which can be maintained for a long time without depleting resources or causing serious damage to the environment] https://dle.rae.es/?id=YSE9w6H and Sustainable as [Which can be sustained or defended with reasons]. https://dle.rae.es/?id=YpjGrNt

Throughout history, the Public Accounting Office has been linked to the development of organizations and economies, facing great challenges to respond to the needs of users, new forms of organization and doing business in a globalized environment. 
Accounting systems, both regulatory and managerial, should consider information for the use of third parties outside the company and the internal information of the organization (its purpose) and the extended equity and its variations, as well as the management of the administrators (their field). Measurements and disclosures of the basic accounting concepts such as equity, profit, value, cost, need to be reconceptualized in view of the environmental issue.

In the new economy of the sustainable society, it will not be guaranteed by the legal conception of ownership and disposition of physical, financial and human capital, but by the control over the visions of future scenarios, ideas about glasnot (information transparency) and the integral frameworks of the decision process. All this will assume the form of intellectual and intangible capital (wealth): one of those intangibles will be the technology of access to nature and the mechanisms of dilution and use of industrial waste.

Torres and Lamb (2012), cite that the training of public accountants is of high regulatory content, they support their training in concrete experiences and in the application of laws and principles for the best organization and business operation, but lack a base and training epistemic that allows them to elaborate and execute projects of scientific and social importance for companies.

This leads to relate social change and social mobility as aspects that face universities that according to their mission and philosophy, have a different orientation, from which they seek to link with employers, efficiently prepare students for participation in the professional field, offering specialized training in the various branches of professional activity, without worrying about a comprehensive and humanistic training aimed at preparing people for life, with a critical sense and social conscience, with a world-centered worldview as an end Last of all and with a humanist concept that allows them to successfully insert themselves into the professional field (Agüero and Torres 2014). Accounting science seeks to determine the elements of cost from an economic approach, to obtain sales prices and it is through the so-called management accounting where costs make sense in an environmental dimension, linked to the operability and decision making of the Business.

\section{Objectives}

Analyze the insertion of Sustainable Development in Public Accounting.

Identify approaches to Sustainable Development in Public Accounting programs

\section{Theoretical Framework}

In April 1987, the Commission for Development and Environment published and released its report, entitled -Our common future- -Our common future-, in the English language also known as the Brundtland Report (Brundtland, $\mathrm{GH}, 1987)$ in the which is introduced the concept of sustainable development, contextualized in these terms: -It is up to humanity to ensure that development is sustainable, that is, to ensure that it meets the needs of the present without compromising the ability of future generations to meet their own -. (Gomez, 2000)

Atristain and Álvarez (1999), move towards the presentation of a new concept by mentioning that sustained development is observed in developed countries that intend to maintain the level of development that they have added to a high ecological awareness, cite the need to include Content study programs related to sustainable development, since the performance of the public accountant is carried out with a global vision.

The 2005-2014 decade has been declared by the UN [the Decade of Education for Sustainable Development]; University institutions must behave as a model of learning and practice for sustainable development, from a double perspective: 1 . From the point of view of the behavior of the entity itself and the impact of the activities developed - teaching, research and management - and 2 From the point of view of the impact of its activity on the rest of society in an environment where higher education, research and innovation are considered key factors to face the challenges of globalization and a society based on knowledge that guarantees the well-being of citizens and sustainable development. Guni, 2004; Vallaeys, 2006 and Lozano, 2006, cited by (Moneva and Martín, 2012). 
The conceptual scope of sustainable development can be divided into three parts: ecological, economic and social, the latter is considered by the relationship between social welfare, environment and economic prosperity.

In May 1999, at the National Meeting on Sustainability held in the US city of Detroit, it was established that the term sustainable development was equivalent to new technologies and new ways of doing business, which would improve the quality of life today in dimensions economic, environmental and social, without damaging the ability of future generations to enjoy that opportunity.

According to Giuseppantonio (2010), sustainability focuses on four key components: 1. Environmental sustainability, 2. Social sustainability, 3. Economic sustainability and 4. Promote culture through international dissemination and local implementation.

It is in management accounting (AECA, 1990) that the environmental dimension takes a true multidimensional content:

First of all, due to its specific purpose and field, management accounting is deeply linked to business administration and the endogenous decision-making process.

Secondly, due to the current conception of the value creation process, which expands the company's vision as a black box and extends it to open systems in networks of interrelation with its ecological environment (social and natural).

From a conceptual point of view management accounting goes from crematistics (search and determination of economic cost elements to set market prices) to ecology (ability to design scenarios that meet the sustainability condition).

Two approaches are recognized in the practical application of sustainable development.

1. Those who study from various accounting and control techniques such as activity-based costing (ABC in English, the quality cost system or environmental accounting and
2. From the point of view of accounting information, it is considered -which is the management accounting in which the environmental issue takes a true multidimensional content- [Spanish Association of Accounting and Business Administration] (AECA, 2003, p.5 ). Increasingly interdisciplinary fields such as ecological in the field of management accounting, need to be linked epistemologically both with the vision that the entrepreneurial culture develops on relations with nature, as with the concrete consideration of the environment in the creation process, distribution and administration of value. Management accounting systems can and should be designed to support the operational level (decrease in pollution in operations, use of clean technologies), tactical (value creation in economic and ecological terms, in business units), and strategic (financial profitability and ecological sustainability) of the company. (Gil, s / f). Environmental accounting was consolidated as a specialized segment of the accounting discipline consisting of several branches: environmental financial, environmental costs or environmental management and environmental audit.

Based on this approach (Gómez, 2009), it indicates that in its constitution process, environmental accounting has had profound impacts on ways of understanding, visualizing and addressing environmental problems, allowing to analyze, classify, summarize and record quantitative and qualitative information of the environmental environment surrounding the company. In this way, it allows to present information regarding the impact generated by the development of commercial activity in the environment along with an evaluation of the economic benefits.

\section{Methodology}

The study involves the collection of data analysis and linking of subjects in sustainable development or similar, based on the subject of Sustainable Development of DACEA, with other universities; It begins as an exploratory to identify the triggering indicators that make up the insertion of the sustainability dimension in the curricula, with a cross-sectional design (Hernández, Fernández and Baptista, 2014), because the data collection takes place in a certain time, to demonstrate the participation in the study programs. 


\section{Results}

The DACEA in 2015 restructures the Bachelor of Accounting program, this reform leads to changes in the curriculum to achieve development in performance skills and transfer to the labor market, the demands and needs of society through a transformation Comprehensive, through the construction of an exit profile with a competency approach that ensures preparation for research, for life and for work -Philosophy of the Educational Model- (PE Restructuring of the LCP, 2016).

Considering the above, the following question arises: Does the inclusion of Sustainability in the programs of the new curriculum of the Curriculum respond to Accounting Science ?; For this purpose, an analysis of the theoretical contributions proposed by various authors who have studied the subject, the creation of degrees in universities, the insertion of the subjects proposed by various universities in the country in their curriculum and the program of Accounting for the Sustainability of the degree in Public Accounting of DACEA, to identify if the knowledge and skills that respond to the demands of the labor market and challenges of change in organizations have been included.

It is necessary that from the academy develop cost structures that allow professionals in Public Accounting to develop skills and competencies in praxis, to respond fully to the specific needs of each company, regardless of their economic activity (Hernández, 2019).

Analyzing the occupational market, the professional services provided to the different sectors of the population must be done with social responsibility, representing an institutional challenge for the rector of the UJAT, in that sense, he affirms that - it will contribute to social welfare, in particular to the most unprotected sectors of the entity, promoting transparent and ethical behavior in the understanding and generation of innovative responses for the multiple dimensions of life in society, including caring for the environment and gender equity. (PD. Long Term, 2028).
To meet the needs of the labor market, DACEA organized an employers' forum with the participation of businessmen and representatives of the National Chamber of the Transformation Industry (CANACINTRA), the National Chamber of Commerce (CANACO) and the National Confederation of the The Mexican Republic (COPARMEX), to answer the question, what type of public accountant do companies demand?

With the interaction that took place between the representatives of the Restructuring Commission of the Bachelor in Public Accounting and professors invited to the event with the employers, two variables were analyzed: work performance and professional competences of the graduates, likewise, the competencies were analyzed professionals from entrepreneurial, administrative, leadership training and the formation of values and attitudes. The result can be verified in Figure 1

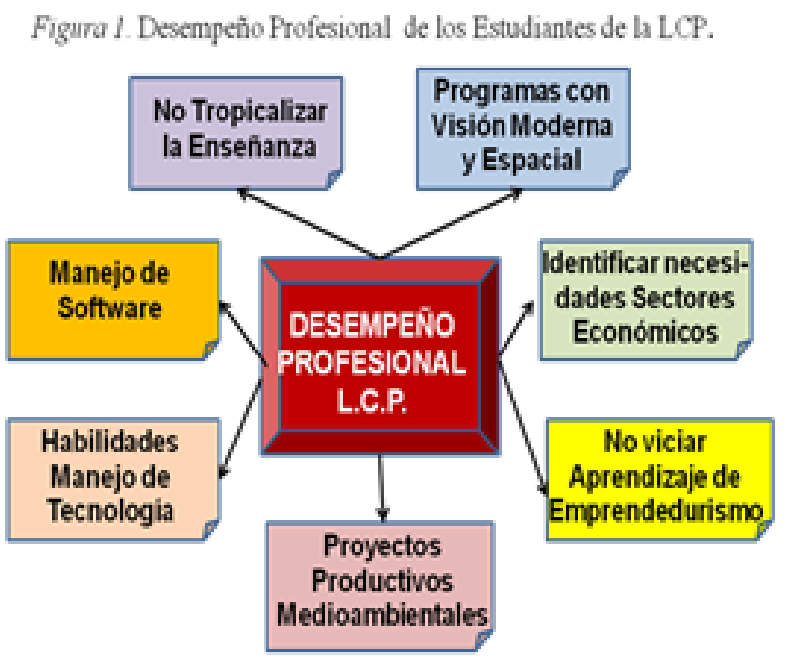

Fuente Forode Empleadores ReestrocturacionPE DE LA LCP 2016

Looking to the future, the new context derived from: Trends of Universities in the next decade, in economic globalization transcends aspects strictly related to an open economy and that operates through the means offered by information and communication technology.

To have a curricular profile of sustainable development programs or similar beyond DACEA, it is necessary to consult other universities in the country to see what is being done on this subject; the portals of some universities were consulted, detecting two actions in this regard: 
1. Universities have offered degrees related to the environmental dimension and

2. Study programs have been designed in Public Accounting or related degrees in this context.

Some of the universities that have designed bachelor's degrees in this area are: Figure 2

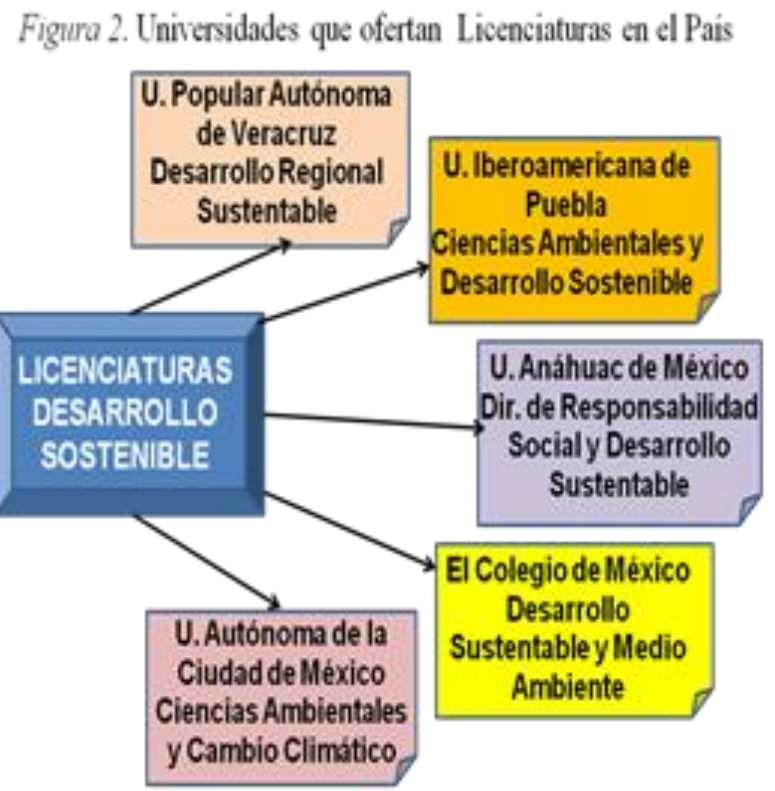

Fuente ConsultaPoutales de las Unir ersidades

Popular Autonomous University of Veracruz

Bachelor: Sustainable Regional

Development.

Iberoamerican University of Puebla

Bachelor's degree: Environmental

Sciences and Sustainable Development

Anahuac University of Mexico

Bachelor's Degree: Social Responsibility and Sustainable Development Department The College of Mexico

- Two-year courses: Advanced studies program in Sustainable Development and Environment.

Autonomous University of Mexico City.

Bachelor of Environmental Science and Climate Change.

Likewise, it was investigated which universities have Sustainable Development programs or similar, making a mapping with National Universities, being considered an international because it is studied by several authors, the following were identified: Figure 3

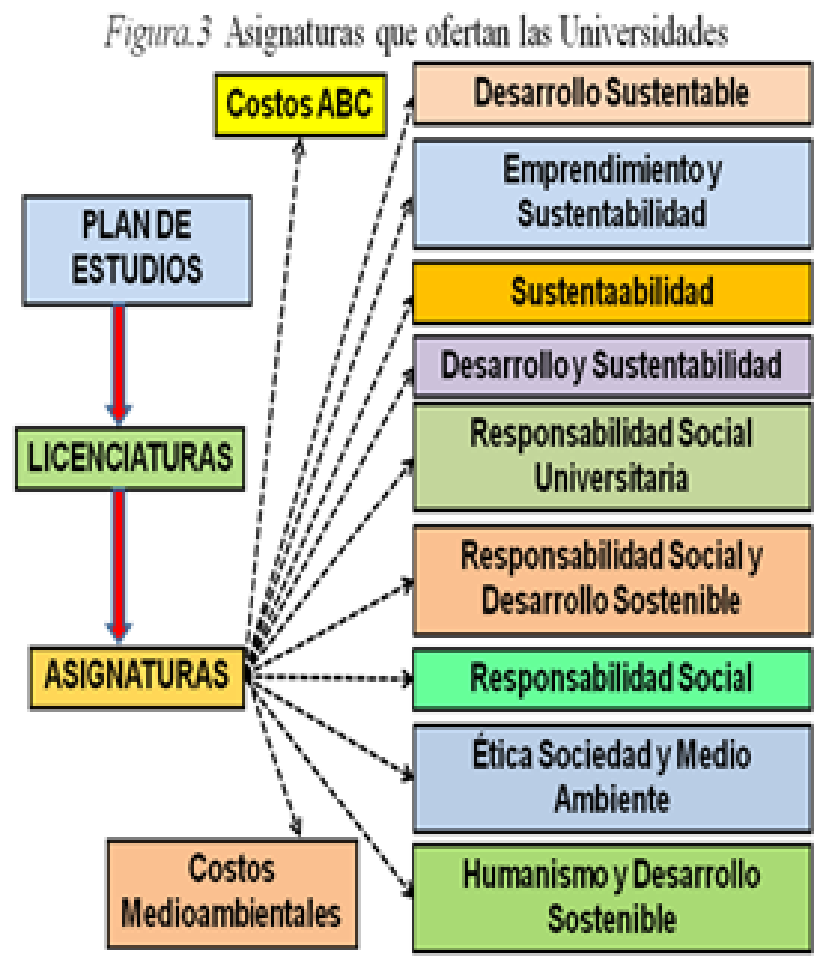

Fuente: ConsultaPotales de las Universidades

National Technological of Mexico Subject: Sustainable Development. Bachelor of Public Accountant

La salle university

Subject: Entrepreneurship and Sustainability.

Bachelor of Accounting and Finance

National Polytechnic Institute

Subject: Sustainable Development.

Bachelor of Public Accountant.

National Autonomous University of Mexico

Subject: ABC costs.

Accounting degree

Subject: Development and Sustainability and Sustainability.

Degree in Ecology

Autonomous University of Yucatan

Subject: University Social

Responsibility.

Degree in Public Accountant

University of the Valley of Mexico

Subject: Social Responsibility and Sustainable Development.

Bachelor of Public Accounting and Finance

Autonomous University of Baja

California

Subject: Social Responsibility.

Accounting degree.

University of the Americas of Puebla 


$\begin{array}{ll}- & \text { Subject: Ethics, Society and } \\ & \text { Environment. } \\ - & \text { Degree in Financial Strategies and Public } \\ & \text { Accounting. } \\ - & \text { Autonomous University of Tlaxcala } \\ - & \text { Subjects: Sustainable Development and } \\ & \text { Humanism and Sustainable } \\ & \text { Development. } \\ - & \text { Degree in public accounting } \\ - & \text { Anahuac University Mexico. } \\ - & \text { Subject: Social Responsibility and } \\ - & \text { Sustainability. } \\ \text { Bachelor of Finance and Public } \\ \text { Accounting. } \\ -\quad \text { University of Havana Cuba } \\ -\quad \text { Subject: Environmental Costs } \\ -\quad \text { Bachelor of Accounting and Finance }\end{array}$

As shown in the analysis, there are universities that offer undergraduate programs with environmental approaches in their curricula, of which five programs were located and, in relation to the Bachelor of Public Accounting, eleven subjects were detected in the environmental approach that are offered with different names, in both public and private universities.

In the restructuring of the DACEA / UJAT curriculum, the thematic contents in the various disciplinary areas were reinforced, strengthening the demands of the labor market detected in research, educational policy, international standards in accounting, financial, auditing, Costs and tax. Emphasis was placed on each level of training and, in the area of transversal training; ethical content, social and business responsibility, sustainable development among others were enriched; The distribution in the curriculum map can be found at: http://www.archivos.ujat.mx/2016/div_dacea/C ontaduria_Publica/MapaCurricular_LCP.pdf The subject of Accounting for Sustainability was designed in the area of transversal training which aims to:

Develop competencies in the field of preparing financial information, which reflects aspects of sustainability and proposes records on accounting regulations in relation to the practices of applying legal provisions related to respect for the environment, as well as the costs of not Respect the applicable regulations.

The subject develops the following Specific Skills:
Apply current norms of sustainability and social responsibility of the economic entities for the registration of the activities inherent to their nature in compliance with the current norm. In their content the following units are generalized without further analysis: Figure 4

\section{- $\quad$ Unit I. Fundamentals of Sustainability \\ - $\quad$ Unit II Global Trends in Environmental Accounting \\ - Unit III Environmental effects and accounting}

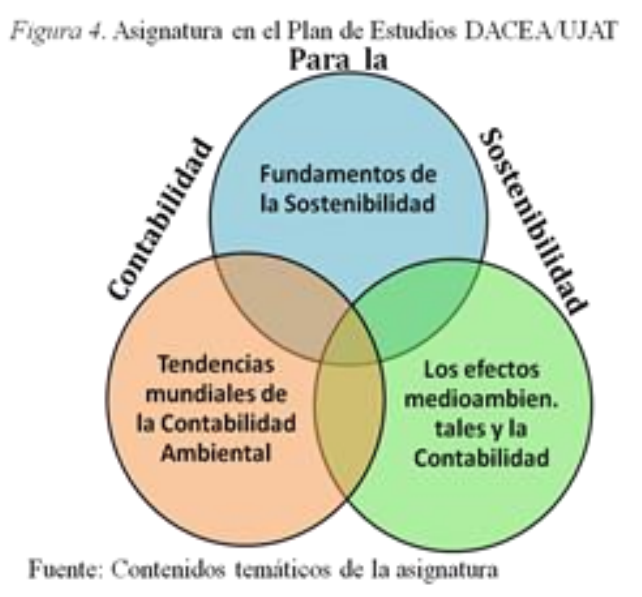

With the data analyzed in published documents and in the findings located in the portals of the country's universities in relation to the offer of degrees and in the study programs on the environmental dimension, it is proposed to enrich the thematic contents of the program of the subject Accounting for the Sustainability of DACEA / UJAT.

In addition to the aforementioned objective and competencies, the thematic units of the subject are broken down, to show the learning that students must acquire to develop the competences of the environmental dimension.

\section{Proposal:}

\section{Subject: Accounting for Sustainability Thematic Content: Unit I. Fundamentals of sustainability}

\subsection{Economic Development and Environment \\ 1.2 Environmental public policies \\ 1.3 Public Policies of sustainable development}

1.4 Bases and strategic framework for sustainable development

1.5 Sustainable use of environmental goods and services

1.6 European and Spanish Union strategy for sustainable development 


\section{Unit II Accounting for Sustainability.}

2.1 Fundamentals of environmental accounting (management)

2.1.1 Methods and cost-volume analysis of operations-benefits for management

2.1.2 Economic valuation methods

2.2 From full costs to variable costs

2.2.1 Direct Costing or variable cost methods

2.2.2 Fixed and variable costs. Simplified Direct Costing

2.2.3 Improved Direct Costing.

2.3 From historical costs to anticipated costs

2.3.1 Budget control

2.3.2 Standard costs

\section{Unit III Environmental costs}

3.1 Recurring environmental costs

3.1.1 Derivatives of obtaining environmental information

3.1.2 Derivatives of an environmental management plan

3.1.3 Derived from environmental technological adaptation

3.1.4 Derived from the management of waste, emissions and discharges

3.1.5 Derivatives of product management

3.1.6 Derived from administrative requirements

3.1.7 Costs derived from the environmental audit.

3.2 Non-recurring environmental costs

3.2.1 Derivatives of information systems and environmental prevention

3.2.2 Derivatives of investments in facilities

3.2.3 Multi-annual conservation and maintenance costs: inspection

3.2.4 Derived from the interruption in the process

3.2.5 Accident Derivatives

3.2.6 Derived from the new demands of the environment

3.2.7 Derived from the improvement of the company's environmental image.

3.2.8 Derivatives of control and measurement systems

3.2.9 Non-disbursable costs

3.2.10 Legal costs

3.2.11 Other specific costs

\section{Unit IV Practical cases}

4.1 Operational study of case studies.

4.1.1 Solve cases related to the environment in:

Nonprofit companies, construction companies, insurance, health centers, public entities, agricultural companies, hotels, town halls, environmental sustainability projects, natural and environmental risks of the company. Other.
4.2 The environmental effects on accounting. 4.2.1 Effects on the environment, social effect, economic effect, effect on implementation and its relationship with accounting.

\section{Final thoughts}

As a result of the studies carried out in the restructuring of the 2015 curriculum in the DACEA / UJAT, the profile of the public accountant is modified to respond to the aforementioned question: what type of public accountant do companies demand?, in Figure 5 the new attributes of the profile are synthesized, which strengthen the training and development of professional skills to face the challenges of the labor field, highlighting for this study the link to corporate and social responsibility.

In relation to the objectives, in the analysis of the curricular map of the degree in public accounting in the DACEA / UJAT, the two aforementioned subjects that strengthen the environmental dimension were located: that of Social Responsibility and Accounting for Sustainability, in addition to identify related topics in various subjects. The content of the subject reason for the analysis was reviewed and the new proposal was made. The indicators that are addressed are shown in Figure 6.

At the country level eleven random subjects were identified with different names that address the environmental approach, the insertion of sustainable development is corroborated with a cost analysis and control approach.

Finally, the opportunity of a new profile of the Public Accountant to strengthen Accounting is confirmed by answering the question: Does the inclusion of sustainability in the programs of the new curriculum of the Curriculum respond to Accounting Science?.

\section{References}

AECA, (1999). Asociación Española de Contabilidad y Administración de Empresas. $L a$ contabilidad de gestión medioambiental. $2^{\mathrm{a}}$. Ed. Marzo. Documento 13 de Comisión de Contabilidad de Gestión. Madrid. 
AECA, (2003). Asociación Española de Contabilidad y Administración de Empresas. El marco de la contabilidad de gestión. $4^{\mathrm{a}}$. Ed. Documento 1 de Principios de Contabilidad de Gestión. Madrid.

AECA, (2019). Asociación Española de Contabilidad y Administración de Empresas. Principios de Contabilidad de Gestión. Madrid. Consulta 20 de junio. Recuperado: https://aeca.es/publicaciones2/documentos/docu mentos-emitidos-principios-de-contabilidad-degestion/

Agüero A. M de y Torres S. J. R. (2014). Panorama de la educación superior en México. Cap. I el futuro de nuestras carreras. Contaduría, Administración e Informática en la sociedad mexicana del siglo XXI. Publicaciones empresariales UNAM-FCA Publishing. Primera reimpresión 9 de junio. ISBN 978-607-02-52242

Atristain, P. y Álvarez R. (1999). La Responsabilidad de la Contabilidad frente al medio ambiente. Instituto Mexicano de Contadores Públicos. ISBN 968-6964-75-4

Chacón, G. B. (2011). La contabilidad de costos en el sistema de información contable. Revista Actualidad Contable FACES, vol. 14, No. 22, Mérida pp.21-44

Cóndor, S. E. J. (2018) Dimensión ambiental en la formación profesional de los estudiantes de la facultad de educación de la Universidad Nacional de Huancavelica. Educación vol. 27 No. 53 Lima set. ISSN 1019-9403. Versión Online ISSN 2304-4322 http://dx.doi.org/10.18800/educacion.201802.0 03

DACEA-UJAT (2016), Reestructuración Plan de Estudios 2015. Licenciatura en Contaduría Pública, aprobada por el $\mathrm{H}$. Consejo Universitario de la UJAT en Agosto 2016, 6 de Junio 2017; Qué es el desarrollo sostenible y por qué es importante? Un modelo de desarrollo que podemos mantener y apoyar, recuperado de: http://www.onu.org.mx/que-es-el-desarrollo

Gil, J. M. (s/f). La contabilidad de gestión en los Paradigmas de administración medioambiental. Recuperado de http://www.observatorioiberoamericano.org/ricg/N\%C2\%BA_1/Jorge_ Manuel_Gil.pdf
Giuseppantonio, V. (2010). Evolución del concepto de desarrollo sostenible. Recuperado de

http://huespedes.cica.es/gimadus/23/09_la_evol ucion_del_concepto_de_desarrollo_sost.html

Gómez. G. C. (2000). Cap. III. El desarrollo sostenible: conceptos básicos, alcance y criterios para su evaluación. Recuperado de http://www.unesco.org/new/fileadmin/MULTI MEDIA/FIELD/Havana/pdf/Cap3.pdf

Gómez, V. M. (2009). Tensiones, posibilidades y riesgos de la contabilidad medioambiental empresarial. Revista Contaduría Universidad de Antoquía,vol. 2 No. 54, Colombia pp. 55-78

Hernández, L. Y. R. (2019). Un cambio paradigmático necesario en la enseñanza de la estructura de los costos en la formación del Contador Público.(A paradigmatic change needed in teaching the structure of costs in Public Accountant training). Revista Encontexto/ISSN: 2346-3279, 7(10), 126-140.

Higuera, O. V. H., Pacheco M. G. A., Lodoño R.S., Cuéllar R.R. y González, F. A. (2017). Contabilidad ambiental, tendencias investigativas mundiales. Artículo original. Enero - junio vol. 1 88-96 DOI: 10.22507/pml,v12n1a9.

Ibarra, G. (1997). Las universidades ante la problemática ambiental. Perfiles Educativos.XIX (78), p. 57-70

Moneva, A. J. M. y Martín, V. E. (2012). Universidad y desarrollo sostenible: Análisis de la Rendición de Cuentas de las Universidades Públicas desde un enfoque de Responsabilidad Social. RIGC - vol. X, No. 19, enero - junio.

Plan de Desarrollo a Largo Plazo. (2028) Universidad Juárez Autónoma de Tabasco. Colección Justo Sierra. Impresión noviembre de 2015. Impreso en México http://www.archivos.ujat.mx/2016/PlanDesarrol loLargoPlazo2028/PLAN_2025_FINAL.pdf

Quinche. F. (2008). Una evaluación crítica de la contabilidad ambiental. Revista Facultad Ciencias Económicas XVI 197-216

RAE. (2019) Real Academia Española. Definición Sostenible. Recuperado 24 de febrero https://dle.rae.es/?id=YSE9w6H 
RAE (2019) Real Academia Española Definición Sustentable. Recuperado 24 de febrero https://dle.rae.es/?id=YpjGrNt

Torres, B. C. y Lamb, W.A. (2012). Los

Fundamentos Epistemológicos de la Contabilidad y su incidencia en la Formación Competitiva del Contador Público. Pontifical Catholic University of Perú. Electronic copy available at: http://ssm.com/abstract=2230419 Sotavento M. B. A. No. 19, enero-junio pp.3250 . 